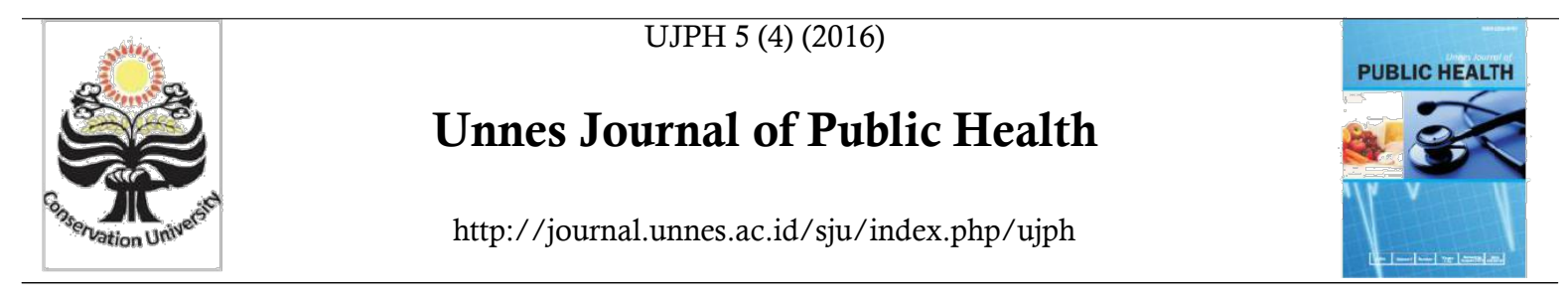

\title{
HUBUNGAN KEBISINGAN MESIN TROMOL DENGAN STRES PEKERJA DI KABUPATEN BONE
}

\author{
Reni Hiola ${ }^{凶}$, dan Atris K. Sidiki \\ Jurusan Kesehatan Masyarakat, Fakultas Olahraga dan Kesehatan, Universitas Negeri Gorontalo, \\ Indonesia
}

\section{Info Artikel

\begin{abstract}
Abstrak
Pemakaian mesin sebagai alat kerja dan mekanisasi dalam industri dapat menimbulkan kebisingan ditempat kerja. Kebisingan dapat mempengaruhi pekerja. Tujuan penelitian ini adalah untuk mengetahui pengaruh kebisingan mesin pengolahan emas (tromol) terhadap stres kerja pada pekerja di pertambangan emas di Desa Dunggilata Kecamatan Bulawa Kabupaten Bone Bolango. Penelitian ini merupakan penelitian survei analitik dengan pendekatan cross-sectional. Data yang diperoleh dianalisis dengan menggunakan uji statistik korelasi Pearson Product Moment. Hasil penelitian menunjukkan, ada hubungan antara kebisingan pada mesin pengolahan emas tromol terhadap stres kerja pada pekerja $(p=0,01)$.
\end{abstract} \\ Sejarah Artikel: Diterima Agustus 2016 Disetujui September 2016 Dipublikasikan Oktober 2016 \\ Keywords: drum- machine; gold-} processing; noise; occupational stress.

\section{Abstract}

The use of the machine in industries may cause noise in workplace which could affect workers. The purpose of this study was to determine the effect of gold-processing drum-machine noise to occupational stress on gold mining workers in the Dunggilata Village, Bulawa Sub-district, Bone Bolango Regency. This was analytic survey with cross-sectional approach. The data were analyzed using Pearson Product Moment Test. The results showed that there was a correlation between noise of gold-processing drum-machine and occupational stress on workers $(p=0.01)$.

(C) 2016 Universitas Negeri Semarang

\footnotetext{
$\bowtie$ Alamat korespondensi:

Jurusan Kesehatan Masyarakat, Fakultas Olahraga dan Kesehatan

Jalan Prof. Dr. Jhon Ario Katili No. 44

Universitas Negeri Gorontalo

E-mail: hiola.reni@gmail.com
}

pISSN 2252-6781 


\section{PENDAHULUAN}

Kemajuan ilmu pengetahuan dan teknologi memberikan kemudahan bagi tenaga kerja dalam melakukan tugasnya, sehingga lebih ringan melakukan kerja fisik, proses produksi lebih cepat dan mutu barang atau hasil produksi lebih berkualitas. Di sisi lain, pembangunan industri dengan penerapan teknologi tinggi dapat memiliki potensi risiko bahaya dan penyakit akibat kerja yang tinggi manakala tidak di dukung oleh peralatan kerja atau mesin yang sesuai dengan prinsip-prinsip keselamatan dan kesehatan kerja (K3) dan dioperasikan oleh tenaga kerja yang memahami K3 itu sendiri.

Pada kawasan industri pertambangan, berbagai permasalahan penyebab stres kerap menjadi perhatian publik dan warga sekitar mengingat industri pertambangan merupakan sektor perekonomian yang area kerjanya berada diluar ruangan dengan menggunakan berbagai peralatan mekanis pendukung yang menimbulkan suara bising (Febriana, 2013). Pertambangan emas memiliki berbagai macam metode pengolahan emas mulai dari amalgamasi hingga bioleaching. Aktivitas penambangan juga mulai menggunakan pemisahan emas dengan menggunakan metode gravitasi melalui pendulangan (panning) dan gelundung (trommel) dan masih banyak yang lainnya. Pengolahan batuan emas yang saat ini banyak digunakan adalah dengan

menggunakan mesin tromol, teknik pengolahan batuan emas ini adalah yang paling sederhana dan termurah serta biasanya digunakan oleh para penambang dalam skala kecil. Mesin tromol berfungsi sebagai penghancur dan penangkap emas dari bahan batuan emas.

Survei awal yang telah dilakukan bahwa pertambangan emas yang ada di Desa Dunggilata dimulai sejak tahun 1992 dan sampai saat ini merupakan pertambangan emas tanpa izin (PETI). Jumlah keseluruhan tempat pengolahan emas yang ada kurang lebih 112 unit yang aktif dan masing-masing unit mempunyai tenaga kerja 2 orang. Oleh karena pertambangan emas ini tidak memiliki izin maka tenaga kerja yang ada di dalamnya tidak memiliki jaminan kesehatan akibat kecelakaan kerja. Minimnya pengetahuan tenaga kerja mengenai kesehatan dan keselamatan kerja mengakibatkan tenaga kerja mengabaikan pentingnya penggunaan alat pelindung diri seperti penggunaan earphone/headset sebagai alat untuk mengurangi kebisingan.

Pemakaian mesin sebagai alat kerja dan mekanisasi dalam industri dapat menimbulkan kebisingan ditempat kerja. Dimana proses industri dipercepat untuk mendapatkan produksi semaksimal mungkin, dengan begitu dampak akibat bising juga meningkat.yang dapat mengganggu daya dengar pekerja. Masa kerja yang biasanya diiringi dengan pengalaman kerja yang meningkat juga dapat mempengaruhi stres yang dirasakan pekerja terhadap pekerjaannya. Kecakapan merupakan salah satu faktor intrinsik pemicu stres yang diperoleh pekerja melalui pengalaman dalam pekerjaannya (Budiyanto dan Yanti, 2010.)

Tingkat kebisingan adalah jumlah getaran/gelombang bunyi atau suara yang masuk di telinga tenaga kerja yang diukur dengan desibel. Dengan kriteria kebisingan < $85 \mathrm{~dB}=$ Memenuhi syarat dan $>85 \mathrm{~dB}=$ Tidak memenuhi syarat. Bell (2001) berpendapat bahwa bising yang berlebih (sekitar 80 desibel) yang berulang kali didengar, untuk jangka waktu yang lama, dapat menimbulkan stress. Banyaknya akibat negatif dari bising sebagaimana diuraikan diatas menimbulkan anggapan bahwa bising juga akan mempengaruhi stabilitas emosi karyawan. Pemerintah menetapkan batas ambang baku kebisingan pada area kerja sesuai 
Keputusan Menteri Tenaga Kerja Nomor KEP.55/MEN/1999, bahwa nilai ambang batas kebisingan di area kerja maksimal 85 dBA dengan waktu pemajanan 8 jam. Menurut Ikron (2005) dalam Hidayat (2012), nilai tingkat kebisingan antara 55-65 dB berpengaruh terhadap gangguan psikologis antara lain gangguan kenyamanan pribadi, gangguan komunikasi, gangguan psikologis seperti stress dan tindakan demonstrasi, gangguan pada konsentrasi belajar, gangguan

istirahat, gangguan pada aktivitas sholat/ibadah, gangguan tidur dan gangguan lainnya, sedangkan keluhan somatik, tuli sementara dan tuli permanen merupakan dampak yang banyak dipertimbangkan dari kebisingan dilingkungan kerja/ industri.

Stres dapat diartikan sebagai suatu kondisi yang terjadi bila transaksi antara individu dengan lingkungan. Adapun gejala stres meliputi tanda seperti sakit kepala, urat bahu dan leher terasa tegang, gangguan pencernaan, nyeri punggung dan leher, keluar keringat berlebihan, merasa lelah, sulit tidur, cemas dan tegang saat menghadapi masalah, sulit berkonsentrasi, mudah marah dan tersinggung. Bagi perusahaan, stres dilihat dalam konteks makna jumlah kemangkiran, kehilangan produktivitas, kinerja yang buruk, kecelakaan, penurunan kreatifitas, dan kurang inovasi (Loocker dan Gregson (2005) dalam Pradana (2013)).

Hasil observasi di Desa Dunggilata

didapatkan hasil pengukuran tingkat kebisingan pada tempat pengolahan emas (Tromol) dengan nilai tingkat kebisingan 89,1 $\mathrm{dB}$ dan hasil wawancara yang telah dilakukan terdapat gambaran psikologis yang mewakili para pekerja bahwa ditemukan gejala stres kerja pada tenaga kerja seperti gangguan pada pendengaran, gangguan fisik, dan hilangnya konsentrasi kerja yang seringkali menyebabkan kecelakaan kerja.Berdasarkan penjelasan diatas peneliti memiliki tujuan untuk mengetahui hubungan kebisingan mesin pengolahan emas (tromol) terhadap stress kerja pada pekerja di pertambangan emas Desa Dunggilata Kecamatan Bulawa Kabupaten Bone Bolango Provinsi Gorontalo.

\section{METODE}

Penelitian ini merupakan penelitian survey analitik dengan menggunakan metode penelitian cross-sectional. Variabel independent dalam penelitian yaitu tingkat kebisingan dan variabel dependent adalah tingkat stres. Populasi penelitian adalah 242 orang yang tersebar pada 112 tromol. Sampel penelitian sejumlah 42 orang yang tersebar pada 20 tromol, diambil menggunakan teknik purposive sampling dengan metode restriksi. Data diperoleh secara langsung dengan mengukur tingkat kebisingan dengan sound level meter dan mengukur stress kerja dengan melakukan wawancara terhadap tenaga kerja pada bagian pengolahan emas di Desa Dunggilata Kecamatan Bulawa Kabupaten Bone Bolango Provinsi Gorontalo. Data yang diperoleh diolah melalui proses tabulasi dan coding serta dianalisis dengan menggunakan uji statistik korelasi Pearson Product Moment.

\section{HASIL DAN PEMBAHASAN}

Penelitian ini dilakukan di penambangan emas Desa Dunggilata Kecamatan Bulawa Kabupaten Bone Bolango, dimana terdapat Penambangan Emas Tanpa Izin (PETI). Telah diketahui ada sekitar 112 tromol dan 6 tong yang aktif dalam pengolahan tiap hari. Setiap pengolahan akan memproduksi hasil samping berupa limbah padat maupun cair.

Hasil wawancara dengan penambang menunjukkan bahwa kegiatan PETI telah dimulai sejak tahun 1992 terutama di tepian sungai Bulawa. Sebagian besar penambang 
menggunakan aliran air sungai untuk memutar tromol sekaligus menjadi tempat pembuangan limbah. Pengolahan emas dengan menggunakan tromol dilakukan setiap hari di hampir semua populasi penelitian, hal ini menunjukkan bahwa tingkat paparan kebisingan yang diterima pekerja cukup tinggi.

Tabel 1. Distribusi tingkat stres berdasarkan umur

\begin{tabular}{|l|l|l|l|}
\hline \multirow{2}{*}{ Umur } & \multicolumn{4}{|l|}{ Tingkat stress } \\
\cline { 2 - 4 } & Ringan & Sedang & Berat \\
\hline $16-20$ & 2 & 3 & 3 \\
\hline $21-25$ & 2 & 15 & 8 \\
\hline $26-30$ & 0 & 3 & 2 \\
\hline $31-35$ & 0 & 1 & 2 \\
\hline $36-40$ & 1 & 0 & 0 \\
\hline
\end{tabular}

Tabel 1 menunjukkan bahwa pada kelompok umur 21-25 terdapat persentase yang paling banyak yakni sebesar 25 orang dengan tingkat stres yang berbeda (stres ringan, stres sedang dan stres berat) sedangkan persentase yang paling rendah yakni pada kelompok umur 36-40 sebesar 1 orang (stres ringan).

Pekerja dengan usia lebih muda lebih banyak mengalami stres kerja dikarenakan pada rentang umur tersebut masa kerjanya masih rendah sehingga keterampilan dan pengalamannya dalam menangani pekerjaannya masih kurang. Selain itu usia muda masih banyak menyimpan harapanharapan yang tinggi atas pekerjaannya. Sedangkan tenaga kerja dengan usia lebih tua telah lebih berpengalaman atas pekerjaannya sehingga tantangan pekerjaan dapat dihadapi dengan lebih mudah. Selain itu usia yang lebih tua telah lebih matang atau dewasa sehingga mampu berpikir lebih realistis dalam mengelola kesenjangan atara harapan dengan kenyataan dalam pekerjaannya (Gatot dan Adisasmito, 2005).

Stres kerja pada pekerja penambangan emas Desa Dunggilata Kecamatan Bulawa Kabupaten Bone Bolango paling banyak terjadi pada kelompok umur 21-25 yakni sebanyak 25 orang dengan tingkat stres yang berbeda-beda (stres ringan, stres sedang dan stres berat). Hal ini dipengaruhi oleh masa kerja pada individu tersebut dimana pada umur 21-25 ini sudah bekerja sejak mereka putus sekolah sehingga tingkat terpaparnya kebisingan sudah sangat lama. Hal ini didukung oleh pendapat dari Pradana (2013) yang menyatakan bahwa tenaga kerja kurang dari 40 tahun paling berisiko terhadap gangguan yang berhubungan dengan stress. Hal ini disebabkan karena pekerja berumur muda dipengaruhi oleh harapan yang tidak realistis jika dibanding dengan yang lebih tua. 
Tabel 2. Distribusi jumlah responden per lokasi tromol

\begin{tabular}{|l|l|}
\hline Unit Tromol & Jumlah Responden \\
\hline 1 & 3 orang \\
\hline 2 & 2 orang \\
\hline 3 & 2 orang \\
\hline 4 & 2 orang \\
\hline 5 & 2 orang \\
\hline 6 & 2 orang \\
\hline 7 & 2 orang \\
\hline 8 & 2 orang \\
\hline 9 & 2 orang \\
\hline 10 & 2 orang \\
\hline 11 & 2 orang \\
\hline 12 & 2 orang \\
\hline 13 & 2 orang \\
\hline 14 & 2 orang \\
\hline 15 & 2 orang \\
\hline 16 & 2 orang \\
\hline 17 & 2 orang \\
\hline 18 & 2 orang \\
\hline 19 & 2 orang \\
\hline 20 & 3 orang \\
\hline
\end{tabular}

Dari tabel 2 dijelaskan bahwa penelitian ini diambil 2 orang pada setiap unit tromol sedangkan pada 2 unit tromol di ambil 3 orang jadi jumlah responden per tromol ada 42 orang responden.

Pengukuran tingkat kebisingan pada pengolahan emas (tromol) dimaksudkan untuk mengetahui apakah tingkat kebisingan pengolahan emas tersebut memenuhi syarat atau tidak. Hasil tingkat kebisingan pengolahan emas (Tromol) di Desa Dunggilata Kecamatan Bulawa Kabupaten Bone Bolango dapat dilihat pada Tabel 3.

Tabel 3 menunjukkan bahwa tingkat kebisingan di semua tromol dalam penelitian ini tidak memenuhi syarat karena hasil pengukuran tingkat kebisingan ini melebihi dari 85 desibel dimana standar kebisingan yakni $<85 \mathrm{~dB}$.
Pengukuran tingkat kebisingan dilakukan dengan alat pengukur kebisingan yakni sound level meter sedangkan alat untuk mengukur stres dengan menggunakan kuesioner H-RSA (Hamilton Rating Scale Anxiety). Dari hasil pengukuran kebisingan diketahui bahwa dari 20 tromol di Desa Dunggilata dinyatakan bahwa keduapuluh tromol tersebut menghasilkan kebisingan melampaui nilai ambang batas yakni 8694,>85 dB (Peraturan Menteri Tenaga Kerja dan Transmigrasi Nomor 13/MEN/X/2011). Untuk tingkat stres dari 42 orang pekerja tromol di Desa Dunggilata ditemukan bahwa orang yang mengalami stres ringan yakni sebanyak 4 orang $(9,76 \%)$, yang mengalami stres sedang yakni sebanyak 24 orang $(58,54 \%)$, dan yang mengalami stres berat yakni sebanyak 34 orang $(34,15 \%)$. 
Tabel 3. Tingkat Kebisingan Pengolahan Emas (Tromol) di Desa Dunggilata Kecamatan Bulawa Kabupaten Bone Bolango

\begin{tabular}{|c|c|c|c|}
\hline No & Unit tromol & $\begin{array}{l}\text { Tingkat } \\
\text { kebisingan }\end{array}$ & Kategori \\
\hline 1 & Tromol 1 & 88.18 & \multirow{20}{*}{ Tidak memenuhi syarat } \\
\hline 2 & Tromol 2 & 92.71 & \\
\hline 3 & Tromol 3 & 89.05 & \\
\hline 4 & Tromol 4 & 87.93 & \\
\hline 5 & Tromol 5 & 87.05 & \\
\hline 6 & Tromol 6 & 86.05 & \\
\hline 7 & Tromol 7 & 87.53 & \\
\hline 8 & Tromol 8 & 94.153 & \\
\hline 9 & Tromol 9 & 88.66 & \\
\hline 10 & Tromol 10 & 86.73 & \\
\hline 11 & Tromol 11 & 86.10 & \\
\hline 12 & Tromol 12 & 89.86 & \\
\hline 13 & Tromol 13 & 89.23 & \\
\hline 14 & Tromol 14 & 87.81 & \\
\hline 15 & Tromol 15 & 90.15 & \\
\hline 16 & Tromol 16 & 88.18 & \\
\hline 17 & Tromol 17 & 87.16 & \\
\hline 18 & Tromol 18 & 88.76 & \\
\hline 19 & Tromol 19 & 87.58 & \\
\hline 20 & Tromol 20 & 91.35 & \\
\hline
\end{tabular}

Tabel 4. Tingkat Stres Pekerja Tromol

\begin{tabular}{|l|l|l|}
\hline Tingkat Stres & Jumlah Responden & $\%$ \\
\hline Tidak ada stres & 0 & 0 \\
\hline Stres ringan & 4 & 9,76 \\
\hline Stres sedang & 24 & 58,54 \\
\hline Stres berat & 14 & 34,15 \\
\hline Stres berat sekali & 0 & 0 \\
\hline
\end{tabular}

Dari tabel 4 dijelaskan bahwa dari 42 pekerja pada pengolahan (tromol) diperoleh hasil yakni orang yang mengalami stres ringan yakni sebesar 4 orang $(9,76 \%)$, stres sedang yakni sebesar 24 orang $(58,54 \%)$ dan yang mengalami stres berat yakni 14 orang $(34,15 \%)$. 
Reni Hiola \& Atris K. Sidiki / Unnes Journal of Public Health 5 (4) (2016)

Tabel 5 Hubungan Tingkat Kebisingan dengan Tingkat Stress

\begin{tabular}{|c|c|c|c|}
\hline Tromol & Tingkat Kebisingan & Tingkat Stres & Nilai $p$ \\
\hline Unit 1 & 88,18 & Sedang dan berat & \multirow{20}{*}{0,010} \\
\hline Unit 2 & 89,05 & Sedang & \\
\hline Unit 3 & 87,93 & Sedang & \\
\hline Unit 4 & 87,05 & Sedang & \\
\hline Unit 5 & 86,05 & Sedang & \\
\hline Unit 6 & 87,53 & Sedang & \\
\hline Unit 7 & 94,15 & Berat & \\
\hline Unit 8 & 88,66 & Sedang & \\
\hline Unit 9 & 86,73 & Sedang dan berat & \\
\hline Unit 10 & 86,1 & Sedang & \\
\hline Unit 11 & 89,86 & $\overline{\text { Berat }}$ & \\
\hline Unit 12 & 89,23 & Berat & \\
\hline Unit 13 & 87,81 & Sedang dan berat & \\
\hline Unit 14 & 90,15 & Berat & \\
\hline Unit 15 & 88,18 & Ringan & \\
\hline Unit 16 & 87,16 & Sedang dan ringan & \\
\hline Unit 17 & 88,76 & Ringan dan sedang & \\
\hline Unit 18 & 87,58 & Sedang & \\
\hline Unit 19 & 91,35 & Sedang & \\
\hline Unit 20 & 92,71 & Berat & \\
\hline
\end{tabular}

Tabel 5 menunjukkan bahwa dari 20 unit tromol terlihat bahwa ada hubungan tingkat kebisingan terhadap tingkat stres kerja.
Tingkat stres yang dialami pekerja bervariasi mulai dari ringan, sedang, dan berat di setiap unit tromol.

Tabel 6 Hubungan tingkat kebisingan dengan tingkat stress

\begin{tabular}{|c|c|c|c|c|c|c|c|}
\hline Tinoleat & \multicolumn{5}{|c|}{ Tingkat stress } & \multirow[b]{2}{*}{ Total } & \multirow[b]{2}{*}{ Nilai $p$} \\
\hline kebisingan & Tidak stres & Ringan & Sedang & Berat & $\begin{array}{ll}\text { Stres } & \text { Berat } \\
\text { Sekali } & \end{array}$ & & \\
\hline $86-88 \mathrm{~dB}$ & 0 & 4 & 20 & 3 & 0 & 27 & \multirow{4}{*}{0,010} \\
\hline $89-91 \mathrm{~dB}$ & 0 & 0 & 2 & 6 & 0 & 8 & \\
\hline $92-94 \mathrm{~dB}$ & 0 & 0 & 2 & 5 & 0 & 7 & \\
\hline Total & 0 & 4 & 24 & 14 & 0 & 42 & \\
\hline
\end{tabular}

Tabel 6 menunjukkan bahwa pada tingkat kebisingan $86-88 \mathrm{~dB}$ terdapat 27 orang mengalami stress kerja dimana terdiri atas stres ringan 4 orang, stres sedang 20 orang, dan berat 3 orang. Terdapat 8 orang yang mengalami stres kerja pada tingkat kebisingan 89-91 dB yang terdiri atas stres sedang sebanyak 2 orang dan stres berat sebanyak 6 orang. Terdapat 7 orang mengalami stress kerja pada tingkat kebisingan 92-95 dB dengan rincian stres sedang 2 orang dan stres berat 5 orang.

Salah satu faktor yang menyebabkan tingkat kebisingan dan stress yang sangat 
signifikan bagi pekerja adalah adanya teknik pengolahan batuan emas yang paling sederhana dan termurah yaitu mesin tromol. Selain itu, dampak akibat bising adalah minimnya pengetahuan tenaga kerja mengenai kesehatan dan keselamatan kerja sehingga mengabaikan alat pelindung pendengaran untuk mengurangi kebisingan padahal alat pelindung diri untuk telinga yang bersifat personal mampu menurunkan efek bising dan sebagai alat proteksi yang lebih baik.

Tingkat kebisingan di 20 sampel penelitian tidak memenuhi syarat karena hasil pengukuran tingkat kebisingan ini melebihi dari 85 desibel dimana standar kebisingan $<85$ dB. Hal ini menujukan bahwa tromol dapat menghasilkan kebisingan yang melebihi nilai ambang batas. Hasil penelitian menunjukkan bahwa $>50 \%$ tenaga kerja mengalami stres sedang. Stres kerja dapat diartikan sebagai sumber atau stressor kerja yang menyebabkan reaksi individu berupa reaksi fisiologis, psikologis dan prilaku. Lingkungan pekerjaan berpotensi sebagai stressor kerja.

Dari hasil uji statistik korelasi pearson product moment menunjukan bahwa ada hubungan yang signifikan antara tingkat kebisingan dengan stres kerja. Hal ini ditunjukan dengan nilai signifikansi $\mathrm{p}=0,010$ atau $\mathrm{p} \leq 0,05$. Hasil penelitian ini sejalan dengan penelitian yang dilakukan oleh Suksmono (2013) dimana hasil penelitian tersebut menunjukan bahwa ada hubungan antara tingkat kebisingan dengan tingkat stres. Kebisingan dapat menjadi stressor bagi pekerja dan menjadi tekanan tambahan dalam melaksanakan pekaerjaan. Tubuh yang menerima stresssor akan bereaksi secara emosi dan fisik agar dapat mempertahankan kondisi fisik yang normal, reaksi tersebut disebut General Adaptation Syndrome (GAS). Reaksi GAS terdiri atas 3 fase yaitu fase waspada/alarm reaction, fase pertahanan/the stage of resistance dan fase kelelahan (Suksmono, 2013).

Pekerja tromol pengolahan emas semuanya terpapar kebisingan karena tak satupun yang mengenakan alat pelindung diri untuk telinga. Selain tidak adanya penyediaan alat pelindung diri untuk telinga, pengetahuan dan kesadaran pekerja tentang kesehatan dan keselamatan kerja memang belum memadai. Endroyo (2010) menyampaikan bahwa faktorfaktor yang mempengaruhi sikap keselamatan dan kesehatan kerja di industri antara lain adalah pendidikan, pengalaman, dan komitmen dari pihak pemberi kerja. Industri pengolahan emas di Desa Dunggilata Kecamatan Bulawa Kabupaten Bone Bolango merupakan penambangan emas tanpa ijin (PETI) sehingga tidak ada komitmen dari pemberi kerja dalam hal menyediaan alat pelindung diri maupun jaminan kesehatan. Pendidikan dan pengalaman masih dapat

ditingkatkan dengan berbagai upaya. Puskesmas dan Dinas Kesehatan setempat dapat mengoptimalkan edukasi dalam pembinaan kesehatan dan keselamatan kerja sektor informal yang mengarah kepada pelaku penambangan emas tanpa ijin dengan tujuan melindungi kesehatan dan keselamatan masyarakatnya. Penelitian Endroyo, et al (2015) menyampaikan bahwa dari hasil eksperimen menunjukkan bahwa kelompok pekerja industri yang diberikan edukasi dan pelatihan yang memadai mengenai kesehatan dan keselamatan kerja menunjukkan sikap dan perilaku yang lebih baik tentang kesehatan dan keselamatan kerja.

\section{SIMPULAN}

Terdapat hubungan antara kebisingan pada mesin pengolahan emas (tromol) terhadap stres kerja pada tenaga kerja ( $p$ $=0,010$ ). Intensitas kebisingan pengolahan emas di Desa Dunggilata Kecamatan Bulawa 
Kabupaten Bone Bolango telah melebihi nilai ambang batas karena lebih dari $85 \mathrm{~dB}$. Penilaian dari 42 pekerja pada pengolahan (tromol) diperoleh hasil yakni orang yang mengalami stres ringan yakni sebesar 4 orang $(9,76 \%)$, stres sedang yakni sebesar 24 orang $(58,54 \%)$ dan yang mengalami stres berat yakni 14 orang $(34,15 \%)$.

\section{UCAPAN TERIMA KASIH}

Ucapan terima kasih kami tunjukkan kepada Kepala Dinas Kehutanan, Pertambangan dan Energi Kabupaten Bone Bolango, serta seluruh responden yang terlibat dalam penelitian ini.

\section{DAFTAR PUSTAKA}

Bell, T.A, Grenn, T.C, Fisher, J.D, Baum, A. 2001. Environment Psychology. New York : Harcourt College Publishers.

Budiyanto, T. dan Pratiwi, E.Y. 2010. Hubungan Kebisingan Dan Massa Kerja Terhadap Terjadinya Stres Kerja Pada Pekerja Di Bagian Tenun "Agung Saputra Tex" Piyungan Bantul Yogyakarta. Jurnal Penelitian dan Kajian Ilmiah Kesehatan Masyarakat. 4 (2): 126-135

Endroyo, B. 2010. Faktor-Faktor Yang Berperan Terhadap Peningkatan Sikap Keselamatan Dan
Kesehatan Kerja (K3) Para Pelaku Jasa Konstruksi Di Semarang. Jurnal Teknik Sipil dan Perencanaan. 12 (2): 111-120

Endroyo, B., Yuwono, B.E., Mardapi, D. 2015. Model of Learning/Training of Occupational Safety \& Health (OSH) Based on Industry in the Construction Industry. Procedia Engineering. 125: 83-88

Febriana, S.K.T. 2013. Faktor-faktor Yang Mempengaruhi Stres Kerja. Jurnal ECOPSY (Jurnal Ilmu Psikologi). 1 (1)

Gatot, D.B. dan Adisasmito, W. 2005. Hubungan Karakteristik Perawat, Isi Pekerjaan dan Lingkungan Pekerjaan terhadap Kepuasan Kerja Perawat di Instalasi Rawat Inap Gunungjati Cirebon. MAKARA KESEHATAN. 9 (1): 1-8

Hidayat, S., Purwanto, Hardiman, G. 2012. Kajian Kebisingan Dan Persepsi Ketergangguan Masyarakat Akibat Penambangan Batu Andesit. Jurnal Ilmu Lingkungan. 10 (2): 95-99

Keputusan Menteri Tenaga kerja Nomor KEP.55/MEN/1999 Nilai Ambang Batas Kebisingan Di Area Kerja.

Pradana, A. 2013. Hubungan Antara Kebisingan Dengan Stres Kerja Pada Pekerja Bagian Gravity. Unnes Journal of Public Health. 2 (3): 10-18

Suksmono. 2013. Hubungan Intensitas Kebisingan dan Iklim Kerja dengan Stres Kerja pada Pekerja Produksi PT. NBI. Unnes Journal of Public Health

2 